\title{
PROFIL KEMAMPUAN NUMERASI SISWA SEKOLAH DASAR BERKEMAMPUAN TINGGI DALAM MEMECAHKAN MASALAH MATEMATIKA
}

\author{
Ana Puspita Maulidina ${ }^{1),}$ Sri Hartatik ${ }^{2)}$ \\ Program Studi Pendidikan Guru SD, Universitas Nahdlatul Ulama Surabaya \\ anapuspita.sd15@student.unusa.ac.id, titax@unusa.ac.id
}

\begin{abstract}
This study aimed to discover the numerical ability of students SD the high-ability in solving mathematical problems This study used a qualitative method. The subject of this study were one students of class II-B SDI Sunan Ampel II Trosobo with a numerical ability test. The instruments used to collect data were in the form of mathematical abilities tests, numeracy ability tests, and interview sheets. Based on the results of the numerical ability test, it showed, The high-ability subjects were able and correct in using a variety of numbers or symbols associated with basic mathematics to solve problems in various contexts of daily life; were able to analyze information displayed in various forms (charts, tables, charts, diagrams and so on); and were able to interpret the results of the analysis to predict and make good decisions.
\end{abstract}

Keywords: Numerical Ability, Problem Solving, Mathematics.

\begin{abstract}
ABSTRAK
Penelitian ini bertujuan untuk mengetahui profil kemampuan numerasi siswa SD berkemampuan tinggi dalam memecahkan masalah matematika Penelitian ini menggunakan metode kualitatif, subjek penelitian ini yaitu 1 siswa kelas II-B SDI Sunan Ampel II Trosobo dengan diberikan tes kemampuan numerasi. Instrumen yang akan digunakan untuk mengumpulkan data berupa tes kemampuan matematika, tes kemampuan numerasi, dan lembar wawancara. Berdasarkan hasil tes kemampuan numerasi menunjukkan, pada subjek berkemampuan tinggi mampu dan benar dalam menggunakan berbagai macam angka atau simbol yang terkait dengan matematika dasar untuk memecahkan masalah dalam berbagai macam konteks kehidupan sehari-hari, mampu menganalisis informasi yang ditampilkan dalam berbagai bentuk (grafik, tabel, bagan, diagram dan lain sebagainya), dan mampu menafsirkan hasil analisis tersebut untuk memprediksi dan mengambil keputusan dengan baik.
\end{abstract}

Kata Kunci: Kemampuan numerasi, Memecahkan Masalah, Matematika

\section{PENDAHULUAN}

Pada saat ini, pembelajaran matematika tidak hanya mengembangkan pada peningkatan kemampuan berhitung, Karena kenyataannya kemampuan berhitung tidak cukup untuk menghadapi masalah kehidupan sehari-hari. Dalam buku (Roebyanto \& Harmini, 2017) mengatakan bahwa kemampuan berhitung hanya sebagian kecil dari matematika, karena sekarang setiap orang harus memiliki kemampuan untuk menghadapi permasalahan baik dalam metamatika maupun kehidupan nyata. Saat ini, di semua jenjang pendidikan mulai diterapkan dengan kemampuan numerasi. Oleh karena itu, manusia harus memiliki kemampuan dalam memecahkan masalah dengan melakukan pemahaman pada suatu masalah, merencanakan untuk menyelesaikan suatu masalah, dan melaksanakan rencana untuk menyelesaikan masalah, serta melihat kembali proses dan hasil penyelesaiaan masalah. Pemecahan masalah merupakan aktivitas sangat penting dalam pembelajaran matematika, karena tujuan belajar yang ingin dicapai dalam pemecahan masalah berkaitan dengan kehidupan sehari-hari. (Susanto, 2013, : 196) dengan demikian pemecahan masalah merupakan suatu proses untuk mencari jalan keluar dari suatu permasalahan untuk mencapai tujuan tersebut. Berdasarkan hasil Tes PISA (Programme for International Student Assesment) pada tahun 2015 menunjukkan bahwa 
Indonesia saat itu menduduki peringkat bawah dalam menerapkan numerasi, bahkan dibawah Vietnam, sebuah negara kecil di Asia Tenggara yang baru saja merdeka. Hasil tes matematika yang diselenggarakan oleh PISA antara Vietnam dengan Indonesia sangat jauh. Vietnam mendapatkan nilai 495 (dengan nilai rata-rata 490), sedangkan Indonesia mendapatkan nilai 387 (Han, Santoso, \& dkk, 2017 : 1).

Berdasarkan hasil observasi pada tanggal 03 November 2018 dikelas II-B SDI Sunan Ampel II Trosobo Kabupaten Sidoarjo, diperoleh informasi tentang kemampuan matematika siswa yaitu: $35 \%$ berkemampuan rendah, $40 \%$ siswa berkemampuan sedang dan $25 \%$ berkemampuan tinggi. Dari hasil tersebut menunjukkan bahwa siswa masih kesulitan dalam menerapkan pengetahuan matematika yang mereka pelajari untuk menyelesaikan permasalahan yang terjadi, yang berkaitan dengan kehidupan sehari-hari. Untuk itu peneliti ingin menganalisis lebih dalam terkait kemampuan numerasi dalam memecahkan masalah matematika pada siswa kelas II SDI Sunan Ampel II Trosobo Kabupaten Sidoarjo.

Menurut (Han, Susanto, \& dkk, 2017 : 3) kemampuan numerasi merupakan kemampuan untuk menerapkan konsep bilangan dan keterampilan operasi hitung di dalam kehidupan seharihari, misalnya, dirumah, pekerjaan dalam kehidupan masyarakat, dan kemampuan untuk menjelaskan suatu informasi yang terdapat di sekitar kita. Kemampuan numerasi dalam PISA (Programme for International Student Assessment) adalah fokus kepada kemampuan siswa dalam menganalisa, memberikan alasan, dan menyampaikan ide secara efektif, merumuskan, memecahkan, dan menginterpretasi masalah-masalah matematika dalam berbagai bentuk dan situasi. (Qasim, Kadir, \& Awaludin, 2015 : 101). Secara sederhana, kemampuan numerasi merupakan kemampuan memahami dan menggunakan matematika dalam berbagai konteks untuk memecahkan masalah, serta mampu menjelaskan kepada orang lain bagaimana menggunakan matematika.

Adapun indikator dalam kemampuan numerasi yang dijelaskan dalam Tabel 1.

Tabel 1. Indikator Kemampuan Numerasi

\begin{tabular}{ll}
\hline No & \multicolumn{1}{c}{ Indikator } \\
\hline 1. & $\begin{array}{l}\text { Menggunakan berbagai macam angka dan simbol yang terkait dengan matematika } \\
\text { dasar untuk memecahkan masalah dalam berbagai macam konteks kehidupan } \\
\text { sehari-hari. }\end{array}$ \\
\hline 2. & $\begin{array}{l}\text { Menganalisis informasi yang ditampilkan dalam berbagai bentuk (grafik, tabel, } \\
\text { bagan, diagram dan lain sebagainya). }\end{array}$ \\
\hline 3. & Menafsirkan hasil analisis tersebut untuk memprediksi dan mengambil keputusan.
\end{tabular}

Sumber: (Han, Susanto, \& dkk, $2017: 3$ )

\section{METODE}

Penelitian ini menggunakan metode penelitian kualitatif yang diupayakan untuk mengamati permasalahan secara sistematis dan akurat mengenai fakta dan sifat objek tertentu. Jenis penelitian ini adalah pendekatan kualitatif yang bersifat deskriptif. Deskriptif yang dimaksud adalah penelitian deskriptif (descriptive research). Penelitian deskriptif adalah penelitian yang dilakukan untuk menggambarkan atau menjelaskan secara sistematis, faktual dan akurat mengenai fakta dan sifat populasi tertentu (Sanjaya \& Wina, 2013 : 59). Penelitian ini 
dilakukan di SDI Sunan Ampel II Trosobo Kabupaten Sidoarjo. Subjek penelitian ini 1 siswa kelas II-B di SDI Sunan Ampel II Troboso Kabupaten Sidoarjo dengan diberikan Tes Kemampuan Numerasi (TKN) untuk menentukan subjek tes kemampuan numerasi peneliti juga menggunakan data pendukung melalui wawancara dengan guru kelas II-B SDI Sunan Ampel II trosobo Kabupaten Sidoarjo.

Dalam penelitian ini subjek penelitian menggunakan teknik purposive sampling. Menurut (Sugiyono, 2016 : 300) purposive sampling merupakan teknik pengambilan sampel sumber data dengan pertimbangan tertentu. Pertimbangan tertentu dalam penelitian ini melalui pertimbangan kategori nilai tinggi, sedang dan rendah. Peneliti disini untuk menentukan subjek penelitian berdasarkan hasil tes kemampuan matematika yang diukur dengan menggunakan kriteria nilai yang berada pada Tabel 2 dibawah ini.

Tabel 2. Kriteria nilai

\begin{tabular}{cc}
\hline Nilai & Kriteria \\
\hline $\mathbf{8 6 - 1 0 0}$ & Kemampuan Tinggi \\
\hline $\mathbf{6 1 - 8 5}$ & Kemampuan Sedang \\
\hline $\mathbf{0 - 6 0}$ & Kemampuan Rendah \\
\hline & Sumber: (Nurul, 2018:32)
\end{tabular}

Instrumen penelitian ini adalah: instrumen utama dan instrumen pendukung. Instumen utama adalah peneliti sendiri sedangkan instrumen pendukung adalah Tes Kemampuan Matematika (TKM) dan Tes Kemampuan Numerasi (TKN). Teknik pengumpulan data dalam penelitian ini adalah menggunakan dokumentasi, wawancara, dan metode tes. Dalam penelitian ini, peneliti menggunakan uji keabsahan data dengan menggunakan uji kredibilitas data dengan menggunakan perpanjangan pengamatan dan triangulasi waktu, uji dependabilitas data, dan uji konfimabilitas.

Dalam penelitian kualitatif, penulis memperoleh data lapangan tentang kemampuan numerasi siswa dalam memecahkan masalah matematika pada siswa kelas II-B SDI Sunan Ampel II Trosobo yang kemudian diolah sehingga diperoleh keterangan yang bermakna, selanjutnya dianalisis. Teknik analisis data yang peneliti gunakan adalah sebagai berikut : pengumpulan data, reduksi data, penyajian data, verifikasi dan kesimpulan.

\section{HASIL DAN PEMBAHASAN}

Berikut adalah hasil dan pembahasan tentang profil kemampuan numerasi siswa SD berkemampuan tinggi dalam memecahkan masalah matematika yang terdapat dari beberapa soal: Pada soal pertama, terdapat soal yang berbentuk denah kemudian siswa diminta untuk menentukan rute perjalanan yang akan dilewati. Pada soal kedua, terdapat soal yang berbentuk diagram piktogram kemudian siswa diminta untuk menghitung operasi hitung perkalian. Dan pada soal ketiga, terdapat soal yang siswa diminta untuk mengelompokkan hewan dan buah berdasarkan jenisnya. Dari beberapa soal tersebut berikut ini adalah paparan hasil kemampuan numerasi siswa SD berkemampuan tinggi dalam memecahkan masalah matematika: 
1. Profil Kemampuan Numerasi siswa SD berkemampuan tinggi dalam memecahkan masalah matematika pada soal pertama

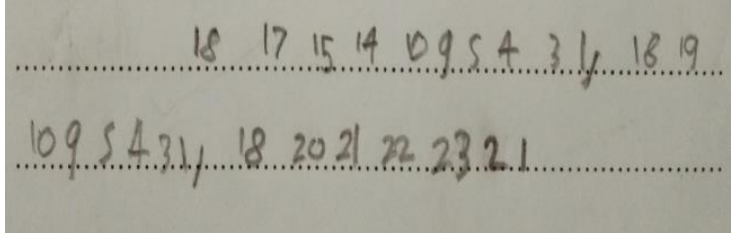

Pada TKN 1

Dari hasil TKN 1 pada subjek kemampuan tinggi yang diperoleh, subjek Kemampuan tinggi dapat menentukan 3 rute perjalanan yang berbeda yang bisa dilewati Edo untuk pergi ke sekolah dengan menggunakan angka dan simbol dalam menuliskan jawaban barisan. Dan diantara 3 barisan jawaban tersebut di pisahkan dengan menggunakan tanda koma (, ).

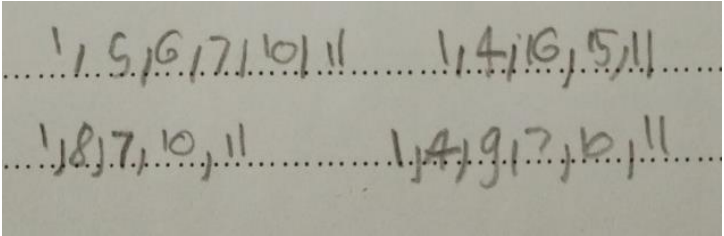

Pada TKN 2

Sedangkan dari hasil TKN 2 pada subjek kemampuan tinggi yang diperoleh, subjek kemampuan tinggi dapat menentukan 4 rute perjalanan yang berbeda yang bisa dilewati Budi untuk pergi ke Masjid. Dengan menggunakan angka dan simbol dalam menuliskan jawaban barisan. Pada setiap satu barisan jawaban subjek kemampuan tinggi dipisahkan dengan menggunakan tanda koma dan diantara 4 barisan jawaban tersebut dipisahkan dengan jarak yang cukup panjang.

Dapat disimpulkan bahwa subjek kemampuan tinggi tersebut mampu memberikan jawaban berbagai barisan rute perjalanan dengan menggunakan berbagai macam angka dan simbol pada soal no 1 yang terkait dengan matematika dasar untuk memecahkan masalah dalam berbagai macam konteks kehidupan sehari-hari dengan berkemampuan baik.

2. Profil Kemampuan Numerasi siswa SD kemampuan tinggi dalam memecahkan masalah matematika pada soal kedua

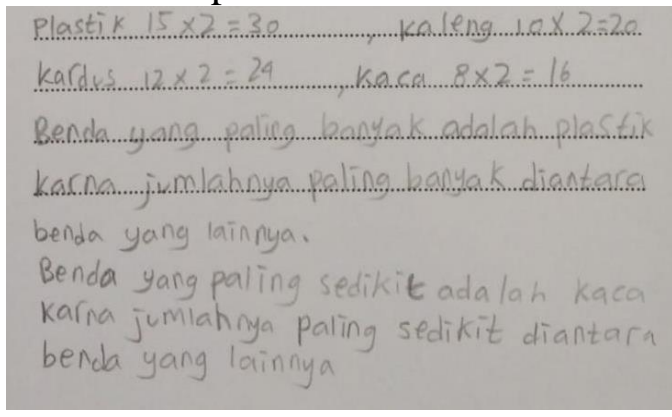

Pada TKN 1

Dari hasil TKN Pertama pada subjek kemampuan tinggi yang diperoleh, subjek kemampuan tinggi dapat memberi jawaban dengan benar dan mampu memberikan alasan. Dalam hal ini siswa mampu menganalisis informasi yang ditampilkan dalam

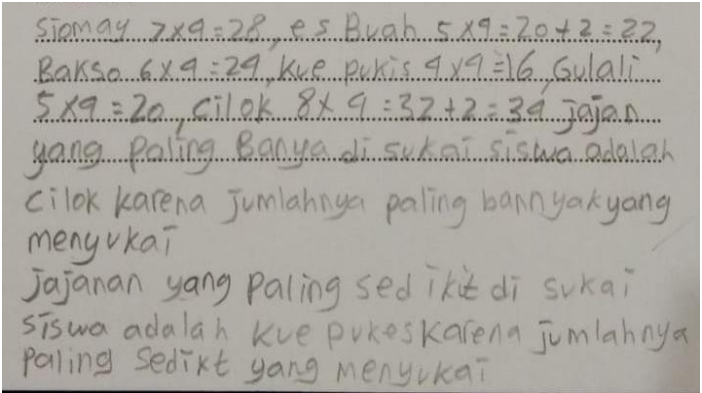

\section{Pada TKN 2}

bentuk diagram piktogram, maka subjek kemampuan tinggi bisa dikatakan berkemampuan baik karena dapat memenuhi syarat atau kriteria sesuai indikator ke-2.

Sedangkan dari hasil TKN Kedua pada subjek kemampuan tinggi yang 
diperoleh, subjek kemampuan tinggi dapat memberi jawaban dengan benar dan mampu memberikan alasan. Dalam hal ini siswa mampu menganalisis informasi yang ditampilkan dalam bentuk diagram piktogram, maka subjek kemampuan tinggi

Dapat disimpulkan bahwa hasil tes kemampuan numerasi pertama dan kedua dalam waktu yang berbeda subjek Kemampuan tinggi tersebut mampu menganalisis informasi yang ditampilkan dalam berbagai bentuk (grafik, tabel, bagan, diagram dan lain sebagainya) dengan berkemampuan baik.

3. Profil Kemampuan Numerasi siswa SD kemampuan tinggi dalam memecahkan masalah matematika pada soal ketiga

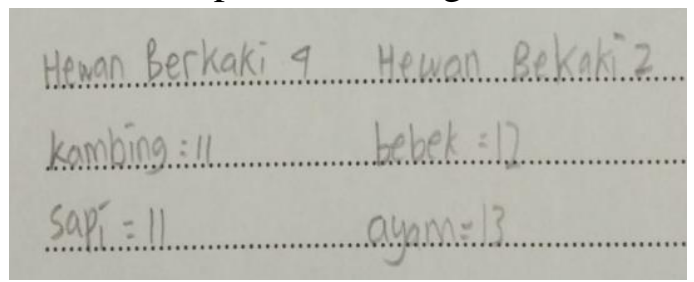

Pada TKN 1

Dari hasil TKN 1 pada subjek kemampuan tinggi yang diperoleh, subjek kemampuan tinggi mampu menjawab dengan benar bahkan mampu menafsirkan hasil analisis tersebut untuk memprediksi dan mengambil keputusan. maka subjek kemampuan tinggi bisa dikatakan berkemampuan baik karena dapat memenuhi syarat atau kriteria sesuai indikator ke-3.

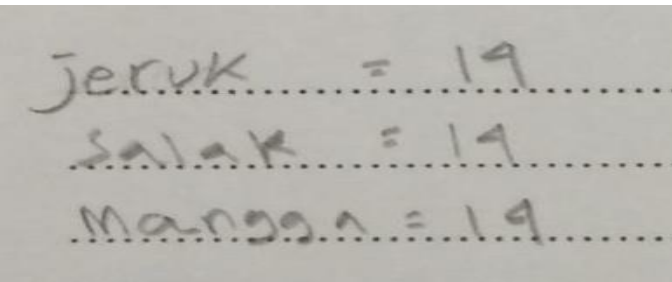

Pada TKN 2

Sedangkan hasil TKN 2 pada subjek kemampuan tinggi yang diperoleh, subjek kemampuan tinggi mampu menjawab dengan benar bahkan mampu menafsirkan hasil analisis tersebut untuk memprediksi dan mengambil keputusan. maka subjek kemampuan tinggi bisa dikatakan berkemampuan baik karena dapat memenuhi syarat atau kriteria sesuai indikator ke-3.

Dapat disimpulkan bahwa hasil tes kemampuan numerasi pertama dan kedua dalam waktu yang berbeda siswa tersebut mampu menafsirkan hasil analisis tersebut untuk memprediksi dan mengambil keputusan. Maka, siswa tersebut dapat dikatakan berkemampuan baik.

Secara umum pada subjek berkemampuan tinggi mampu dan benar dalam menggunakan berbagai macam angka atau simbol yang terkait dengan matematika dasar untuk memecahkan masalah dalam berbagai macam konteks kehidupan sehari-hari, mampu menganalisis informasi yang ditampilkan dalam berbagai bentuk (grafik, tabel, bagan, diagram dan lain sebagainya), dan mampu menafsirkan hasil analisis tersebut untuk memprediksi dan mengambil keputusan dengan baik. Hal tersebut dapat didukung oleh teori (Qasim, Kadir, \& Awaludin, 2015 : 101) bahwa kemampuan Numerasi dalam PISA adalah fokus kepada kemampuan siswa dalam meganalisa, memberikan alasan, 
menyampaikan ide secara efektif, merumuskan, memecahkan, dan menginterpretasi masalah-masalah matematika dalam berbagai bentuk dan situasi.

\section{KESIMPULAN}

Dari hasil dan pembahasan yang sudah dijelaskan tentang profil kemampuan numerasi siswa SD berkemampuan tinggi dalam memecahkan masalah matematika mampu dan benar dalam menggunakan berbagai macam angka atau simbol yang terkait dengan matematika dasar untuk memecahkan masalah dalam berbagai macam konteks kehidupan sehari-hari, mampu menganalisis informasi yang ditampilkan dalam berbagai bentuk (grafik, tabel, bagan, diagram dan lain sebagainya), dan mampu menafsirkan hasil analisis tersebut untuk memprediksi dan mengambil keputusan dengan baik.

\section{DAFTAR PUSTAKA}

Han, W., Santoso, D., \& dkk. (2017). Materi Pendukung Literasi Numerasi. Jakarta: Kementrian Pendidikan dan Kebudayaan

Nurul. (2018). Analisis Kemampuan Siswa Dalam Memecahkan Masalah Dalam Bentuk Soal Cerita Bangun Datar Menggunakan Tahapan Polya di SD AL-HIKMAH Simo Kalanagan Surabaya.

Qasim, Kadir, \& Awaludin. (2015). Deskripsi Kemampuan Literasi Matematika Siswa SMP Negeri DiKabupaten Buton Utara. Jurnal Penelitian Pendidikan Matematika Volume 3 No 3 .

Roebyanto, G., \& Harmini, S. (2017). Pemecahan Masalah Matematika. Bandung: PT Remaja Rosdakarya.

Sanjaya, \& Wina. (2013). Penelitian Pendidikan, Jenis Metode dan Prosedur. Jakarta: Prenada Media Group. 